\title{
ASSESSING THE DAMAGE: MONEY AWARDS BY THE OHRT IN SEXUAL HARASSMENT CASES
}

\author{
HONOR M. LAY*
}

\section{INTRODUCTION}

The Ontario Human Rights Code (the Code) ${ }^{1}$ prohibits sexual harassment, which includes both verbal sexual harassment and physical sexual harassment (sexual assault). Individuals who experience sexual harassment in employment, housing, education, or other social services in Ontario may be entitled to a general damages remedy under section 45.2 of the Code. The Ontario Human Rights Tribunal (OHRT) has granted this award in more than thirty sexual harassment cases ${ }^{2}$ since 2000 . Viewed together, the thirty decisions analyzed in this paper reveal certain trends in the tribunal's legal reasoning when dealing with sexual harassment cases. The OHRT conducts an objective analysis of the severity of the harasser's conduct, followed by a subjective analysis into the impact of the incident on the applicant. The objective and subjective analyses are directly related to the determination of damage awards: the more objectively severe the harassment, or the greater the impact on the applicant, the higher the general damages award to the applicant.

At the root of the OHRT's approach to the subjective impact analysis is its expectation that an applicant will visibly demonstrate to the tribunal that the respondent's conduct caused them distress or traumatization. In fact, frequently the OHRT will expect medical proof or other evidence of the applicant's emotional or psychological suffering. Lack of evidence will often adversely affect the applicant's entitlement to higher damage awards.

The requirement to produce medical proof constitutes an invasion of the applicant's right to medical privacy. Moreover, the notion that an individual who experiences sexual harassment will react to the experience in a manner recognizable to a tribunal, or quantifiable in medical evidence, perpetuates the myth of the "ideal victim" in human rights law. ${ }^{3}$ The image of the hysterical woman and other stereotypes of what "real" victims look like discount the experiences of applicants who deviate from this

Copyright $\odot 2019$ by HONOR M. LAY.

* Honor Lay is a recent JD graduate of Western University. Honor would like to thank the editors of the Western Journal of Legal Studies and Professor Melanie Randall for her guidance and encouragement.

${ }^{1}$ Human Rights Code, RSO 1990, c H.19 [Code].

${ }^{2}$ See Appendix A for a list of the 30 recent sexual harassment decisions relating to the general damages provision of s 45.2 that were consulted in writing this paper.

${ }^{3}$ Melanie Randall, "Sexual Assault Law, Credibility, and 'Ideal Victims': Consent, Resistance, and

Victim Blaming” (2010) 22:2 CJWL 397 at 398, DOI: <10.3138/cjwl.22.2.397>. 
archetype and strip applicants of their right to legal redress for the harm they have endured.

\section{OVERVIEW OF SECTION 45.2}

Sexual harassment is a form of discrimination based on $\operatorname{sex}^{4}$ that is prohibited under the Code. ${ }^{5}$ Sexual harassment is an umbrella term that encompasses a range of behaviours from verbal harassment, such as sexual jokes or gossip, to sexual assault, meaning any kind of unsolicited physical contact of a sexual nature. ${ }^{6}$ Part I of the Code protects an individual's right to be free from sexual harassment in employment, housing, education, and other public service areas protected under the Code. Employers, landlords, education providers, and providers of other social services have a positive legal duty to protect against discrimination and harassment within their respective sectors. ${ }^{7}$

If an individual experiences sexual harassment in any of these environments, the individual may choose to file a complaint with the OHRT. When the applicant successfully proves that sexual harassment took place, the OHRT may order one or more of the following remedies:

1. An order directing the party who infringed the right to pay monetary compensation to the party whose right was infringed for loss arising out of the infringement, including compensation for injury to dignity, feelings and self-respect [the general damages remedy];

2. An order directing the party who infringed the right to make restitution to the party whose right was infringed, other than through monetary compensation, for loss arising out of the infringement, including restitution for injury to dignity, feelings and self-respect [the restitution remedy];

3. An order directing any party to the application to do anything that, in the opinion of the Tribunal, the party ought to do to promote compliance with this Act [the future compliance remedy]. ${ }^{8}$

The OHRT will usually apply the following analysis when determining whether to award general damages. First, the OHRT applies the Arunachalam principle ${ }^{9}$ by

\footnotetext{
${ }^{4}$ Janzen v Platy Enterprises Ltd, [1989] 1 SCR 1252 [Janzen] (first recognition of sexual harassment as a form of discrimination based on sex).

${ }^{5}$ Code, supra note $1, \mathrm{~s} 7$.

${ }^{6}$ Janzen, supra note 4 at 1277 (citing Bell v Ladas (1980), 1 CHRR D/155 (Ont Bd Inquiry) at D/156).

${ }^{7}$ Renu Mandhane, "2015 Summit on Sexual Violence and Harassment" (Speaking Notes delivered at the 2015 Summit on Sexual Violence and Harassment, 19-20 November 2015), online: <www.ohrc.on.ca/en/2015-summit-sexual-violence-and-harassment> [perma.cc/ZZ6H-FLPQ].

${ }^{8}$ Code, supra note 1 , s 45.2(1).

${ }^{9}$ As established in Arunachalam v Best Buy Canada Ltd, 2010 HRTO 1880.
} 
considering the seriousness of the conduct (the objective analysis) and the impact of the conduct on the applicant (the subjective impact analysis). The OHRT established this two-pronged approach to determine general damages in Arunachalam, explaining that "more prolonged, hurtful, and serious" conduct ought to register higher on the damages spectrum. ${ }^{10}$ Likewise, "when the applicant has experienced particular emotional difficulties as a result of the event, and when his or her particular circumstances make the effects particularly serious," this also weighs in favour of a higher award. ${ }^{11}$

Second, the tribunal will usually consider ADGA Group Consultants Inc $v$ Lane, ${ }^{12}$ a case that set out specific factors to consider when determining a general damages award for discrimination. These factors include "humiliation; hurt feelings; the loss of self-respect, dignity, and confidence by the complainant; the experience of victimization; the vulnerability of the complainant; and the seriousness of the offensive treatment." 13 Next, the OHRT will generally evaluate and articulate whether the sexual harassment was objectively serious. Finally, the tribunal will assess and articulate the subjective impact of the sexual harassment on the applicant, if any, based on the applicant's own testimony and other evidence, such as medical proof.

The OHRT will then consider the general damages awards ordered in previous decisions, noting that the awards for sexual harassment in employment cases (the most common circumstance in which sexual harassment allegations arise) have ranged from $\$ 12,000$ to $\$ 150,000 .{ }^{14}$ The tribunal will state that decisions lower on the spectrum (less than $\$ 12,000$ ) tend to involve cases in which the OHRT has "found that there were few incidents, the incidents were of a less serious nature, and/or the incidents did not include physical touching." 15 Cases on the high end of the spectrum, generally between $\$ 15,000$ and $\$ 50,000$, tend to be instances where the tribunal has "found that there were multiple incidents, the incidents were of a serious nature, there was a serious physical assault or criminal conviction and/or there was a reprisal or a loss of employment related to the incidents." 16 In one exceptional case, general damages of $\$ 150,000$ were awarded where an employer repeatedly sexually assaulted two temporary workers from Mexico, threatening deportation if they refused. ${ }^{17}$ The OHRT will finally situate the case at hand on the spectrum — on the lower, middle, or higher end - and typically will briefly justify why that placement and quantum ordered is appropriate.

${ }^{10} \mathrm{Ibid}$ at paras 52-53.

${ }^{11}$ Ibid at para 54.

${ }^{12}$ (2008), 91 OR (3d) 649 (Div Ct).

${ }^{13} \mathrm{Ibid}$ at para 154.

${ }^{14}$ See e.g. de los Santos Sands v Moneta Marketing Solutions Inc, 2016 HRTO 271 at para 50 [Santos Sands].

${ }^{15}$ Ibid at para 51.

${ }^{16}$ Ibid.

${ }^{17}$ OPT v Presteve Foods Ltd, 2015 HRTO 675 [OPT]. 
The OHRT's approach of evaluating the conduct from both objective and subjective perspectives is significant. The tribunal's concern is not limited to whether the respondent's conduct was extreme (and thus whether to award a larger sum), as that is only part of the analysis. The extent to which the conduct affected the applicant is also important. This consideration ensures that applicants who are significantly impacted are still entitled to monetary compensation regardless of whether the conduct was objectively serious. As a result, in the context of sexual harassment, applicants who suffer sexual assault (i.e., objectively serious forms of sexual harassment) are not the only individuals entitled to damage awards. As the case law indicates, applicants who endure verbal sexual harassment are also entitled to damage awards where the conduct clearly caused them emotional or psychological trauma.

Although the OHRT's subjective impact analysis often supports entitlement to general damages, the same inquiry can also undermine the applicant's access to compensation. The analysis of the cases in the following section highlights that where applicants do not appear to have been harmed by the respondent's conduct-i.e., if their injury to "dignity, feelings and self-respect" is not made visible to the tribunal-this influences the tribunal's determination of an appropriate remedy under section 45.2.

\section{OHRT JURISPRUDENCE AND THE OHRT APPLICATION OF SECTION 45.2}

\section{The Objective Conduct Analysis}

\section{Sexual Assault or Verbal Harassment?}

One of the most important factors the OHRT will consider when determining whether the respondent's conduct was objectively serious (and thus whether to order higher damages) is whether the respondent physically touched-i.e., sexually assaulted-the applicant. In Horner $v$ Peelle Company $L t d,{ }^{18}$ the tribunal determined that "the objective seriousness of the conduct complained of was in the low end of the range" because "[t]he applicant was not groped, touched, or kissed; rather, the respondent's owner leaned towards her and asked for a kiss." ${ }^{19}$ Other cases have similarly held that where the harassment is verbal only, the case is generally situated on the lower end of the spectrum, ${ }^{20}$ unless the facts otherwise justify moving the award higher up the damages spectrum. ${ }^{21}$

Related to the question of the objective seriousness of the respondent's behaviour is whether the respondent was already criminally charged for the same

\footnotetext{
182014 HRTO 1211 [Horner].

${ }^{19}$ Ibid at para 216.

${ }^{20}$ Wesley v 2252466 Ontario Inc, 2014 HRTO 1591 [Wesley]; Manu v Centum Fundamental Financial Inc, 2015 HRTO 725 [Manu]; Chuvalo v Toronto Police Services Board, 2010 HRTO 2037 [Chuvalo].

${ }^{21}$ SS v Taylor, 2012 HRTO 1839 [SS].
} 
conduct at issue before the tribunal. In $G G v[\ldots]$ Ontario Limited, ${ }^{22}$ the OHRT accepted the respondent's previous criminal conviction of sexual assault for the same conduct as proof that the conduct was objectively serious in nature. In another case, SH v M [...] Painting, ${ }^{23}$ the tribunal also found the respondent's conduct to be objectively serious based on an earlier criminal conviction of criminal harassment. In this case, the OHRT noted that the respondent had "admitted in the course of the guilty plea that he engaged in inappropriate ... touching on a daily basis." ${ }^{24}$ Thus, where the applicant successfully brings criminal charges against the respondent for the sexual misconduct, the tribunal will accept that criminal conviction as sufficient proof of the objective seriousness of the case and as grounds for greater monetary compensation to be awarded.

While it is generally true that verbal harassment registers lower on the remedy spectrum and sexual assault on the higher end, the OHRT is willing to recognize the objective seriousness of verbal harassment cases if the facts merit that determination. For instance, in SS $v$ Taylor, the respondent had sent several inappropriate text messages to the applicant and left one extremely vulgar voicemail on her answering machine. The respondent, the applicant's superior, told the applicant that he could guess the colour of her nipples, texted her that he had dreamt about her nipples and showering with her, and left her a voicemail—with other male employees heard laughing in the background-stating:

[W]e hear that you can squirt about a good 10 feet. I want you to ping-pong. I want it flying out of your cunt like a massive fucking truckload of great fucking pussy juice. ... Please have my children. ${ }^{25}$

In this instance, the OHRT promptly concluded that the conduct was "very serious." 26 The tribunal explained that the respondent's comments were "markedly demeaning, humiliating and hurtful" and that "[t]he voicemail message, in particular, was made in circumstances that seemed designed to cause the utmost level of pain and humiliation to the applicant," given that the respondent left the voicemail in the company of other male employees, who were co-workers of the applicant. ${ }^{27}$

\footnotetext{
222012 HRTO $1197[G G]$.

232009 HRTO 595 [SH].

${ }^{24} \mathrm{Ibid}$ at para 84.

${ }^{25}$ SS, supra note 21 at para 26.

${ }^{26} \mathrm{Ibid}$ at para 84.

${ }^{27}$ Ibid.
} 


\section{An Isolated or Repetitive Incident?}

Whether the respondent's conduct was an isolated incident or recurring behaviour also factors into the tribunal's determination of whether the conduct is objectively serious or not and thus whether greater damages are merited. For instance, in one situation where the respondent pulled the applicant onto his lap, forcefully kissed her, and touched her breasts, the OHRT found it significant that it happened only once, stating that "the fact that this was a single incident and one that was not premeditated lessens its relative seriousness." 28 The tribunal regularly finds that repetitive sexual harassment over several months or years is significant in elevating the objective seriousness of the claim and granting higher damages. ${ }^{29}$

\section{Power Imbalance and Vulnerability}

The respondent being in a position of authority over the applicant often increases the objective severity of the conduct and factors into the decision to offer greater compensation. Power imbalance is often relevant in cases of sexual harassment in the workplace, where the respondent is the employer of, or in some other position of authority over, the applicant-employee. ${ }^{30}$ Where the applicant-employee is subsequently fired for failing to submit to the respondent, this may persuade the OHRT to increase the award. ${ }^{31}$ For example, in $C U v$ Blencowe, ${ }^{32}$ the tribunal explained:

The respondent was not the applicant's supervisor, but held a more senior position than the applicant and, as a result, her perception was that she could lose her job if she complained about his behaviour. Accordingly, I find that the applicant was in a vulnerable position, as employees often are. ${ }^{33}$

The OHRT has also drawn attention to obvious power imbalances in nonemployment cases, such as in professional service relationships or landlord-tenant arrangements. In Manu $v$ Centum Fundamental Financial Inc,${ }^{34}$ the applicant, a woman

\footnotetext{
${ }^{28} G G$, supra note 22 at para 26.

${ }^{29}$ See JD v The Ultimate Cut Unisex, 2014 HRTO 956 [JD]; Garofalo v Cavalier Hair Stylists Shop Inc, 2013 HRTO 170 [Garofalo]; Vipond v Ben Wicks Pub and Bistro, 2013 HRTO 695 [Vipond]; CU v Blencowe, 2013 HRTO 1667 [CU]; SS, supra note 21; Hughes v 1308581 Ontario, 2009 HRTO 341 [Hughes]; SH, supra note 23.

${ }^{30}$ See Santos Sands, supra note 14; GG, supra note 22; SS, supra note 21; Cugliari v Telefficiency Corporation, 2006 HRTO 7.

${ }^{31}$ See e.g. CU, supra note 29; Chuvalo, supra note 20; Garofalo, supra note 29; Horner, supra note 18; MK v [...] Ontario, 2011 HRTO 705 [MK]; Newton v Toronto (City), 2010 HRTO 1023 [Newton]; Ratneiya v Daniel \& Krumeh, 2009 HRTO 1824 [Ratneiya]; Smith v Menzies Chrysler, 2009 HRTO 1936; Smith v The Rover's Rest, 2013 HRTO 700 [Rover's Rest]; Vipond, supra note 29.

${ }^{32}$ CU, supra note 29.

${ }^{33}$ Ibid at para 35.

${ }^{34}$ Manu, supra note 20.
} 
in her mid-twenties who was a first-time home buyer, relied on her mortgage agent, the respondent, to help her purchase a condominium. Given the fiduciary nature of this relationship, the tribunal found that the respondent preyed on her "during a time that she was particularly vulnerable and dependent on [him]." ${ }^{35}$ In Hill-LeClair v Booth, ${ }^{36}$ a case where the applicant rented a room in the respondent landlord's house, the OHRT highlighted the extreme abuse of power by the respondent, who invaded her privacy in the home and used the threat of eviction to further encroach on her life. ${ }^{37}$

The OHRT will take into account other indicia of vulnerability, such as the applicant's age, history of past abuse, single-mother status, or other minority status. Tribunals will tend to judge the respondent's actions to be particularly severe where the applicant is young ${ }^{38}$ or a minor, ${ }^{39}$ a single-mother, ${ }^{40}$ an ethnic minority, ${ }^{41}$ a migrant worker, ${ }^{42}$ disabled, ${ }^{43}$ homosexual, ${ }^{44}$ or has a history of past abuse. ${ }^{45}$ The OHRT clearly recognizes that a respondent's conduct that cuts across several intersectional ${ }^{46}$ layers of oppression ought to register high on the remedy spectrum. In one decision, the tribunal specifically noted "intersectionality" as relevant to its decision to award an additional $\$ 3,000$ to the applicant, a woman of colour. ${ }^{47}$

\section{The Subjective Impact Analysis}

As previously mentioned, the OHRT does not consider only the objective severity of the respondent's conduct in fixing general damages; it will also take into account the subjective impact of the conduct on the applicant. An applicant who succeeds in demonstrating that he or she has suffered injury to "dignity, feelings and self-respect" will generally persuade the tribunal to order a higher award for compensation.

There is reason and compassion behind the subjective impact analysis. Many individuals may agree that unwanted sexual advances would be objectively harmful to

\footnotetext{
${ }^{35}$ Ibid at para 46.

362009 HRTO 1629 [Hill-LeClair].

${ }^{37}$ Ibid at para 43.

${ }^{38}$ Ibid.

${ }^{39}$ JD, supra note 29.

${ }^{40}$ Hill-LeClair, supra note 36; Garofalo, supra note 29; Rover's Rest, supra note 31.

${ }^{41}$ SH, supra note 23 (aboriginal ancestry considered to be minority status by the OHRT).

42 OPT, supra note 17.

${ }^{43}$ Wesley, supra note 20.

44 Ibid.

${ }^{45}$ Hughes, supra note 29.

${ }^{46}$ Intersectionality refers to the interconnection of oppressive forces such as racism, sexism, homophobia, ableism, transphobia, and classism. The theory argues that individuals who are exposed to multiple oppressive forces tend to experience enhanced oppression and marginalization in society.

${ }^{47}$ Manu, supra note 20 ("I have also considered that there is some overlap or intersection of grounds in the discrimination that the applicant [a black woman] experienced" at para 50).
} 
another person. However, how an individual experiences sexual harassment or sexual assault varies, and every applicant is different. Following an incident, an individual may have to change jobs, move neighbourhoods, alter the way they dress, fear that they will lose their job, pay for counselling, lose sleep, or have their own personal relationships suffer. Therefore, it is reasonable for a tribunal to take subjective personal impacts into consideration and decide whether to award the applicant a higher sum of money.

It might be expected that subjective impact analysis would provide greater opportunity for applicants to secure higher damage awards than would be awarded if the OHRT only employed an objective analysis of the respondent's conduct. However, section 45.2 is a discretionary provision. It provides that the tribunal may award damages for "loss arising out of the infringement, including ... injury to dignity, feelings, and self-respect." 48 Thus, if applicants fail to demonstrate such loss, the OHRT may exercise its discretion to not award any monetary compensation or, more commonly, to award smaller monetary sums.

Accordingly, the tribunal tends to approach the subjective impact analysis from a binary standpoint: if the applicant shows signs of distress or emotional harm, it will order a higher award; conversely, if the distress or harm on the applicant is not visible to the tribunal, it will either decline to raise the award or, in some cases, lessen the award. Fortunately, there are also exceptional cases where the repercussions on the applicant are not particularly evident or visible, but the OHRT resolves nevertheless to award what they conclude to be reasonable compensation based on the facts.

\section{The Importance of Medical Evidence}

Upon review of the thirty tribunal decisions, it appears that the language "injury to dignity, feelings and self-respect" has a tendency to limit the OHRT into screening for the "ideal victim," namely, behaviour indicative of distress or traumatization. When an applicant attests to having suffered emotional or psychological suffering that resonates with the words "injury to dignity, feelings and self-respect," the tribunal generally highlights this and justifies the award granted on the basis that the applicant was significantly impacted by the sexual harassment. This is particularly the case where the applicant adduces medical evidence that substantiates the emotional and psychological trauma suffered. However, the OHRT has stated that where an applicant does not demonstrate "injury to dignity, feelings and self-respect" or manifests some other reaction that does not neatly fit the "ideal victim" stereotype, this missing element will usually factor into the lesser amount of damages awarded. ${ }^{49}$

\footnotetext{
${ }^{48}$ Code, supra note 1 at para 45.2.

${ }^{49}$ Payette v Alarm Guard Security Service, 2011 HRTO 109 at paras 53-54 [Payette].
} 
It is concerning how much weight the OHRT places on medical evidence in substantiating the applicant's entitlement to general damages. In $C K v H S,{ }^{50}$ the tribunal found that the applicant's medical documentation attested to "the psychological consequences of the respondent's misconduct." 51 From this, the tribunal concluded, that "the evidence establishe[d] that the sexual harassment experienced by the applicant has had a profound effect on her" and that the evidence "support[ed] an award of damages for injury to dignity, feelings and self-respect at the upper end of the range." 52 There are numerous other decisions where the tribunal refers specifically to medical reports in its reasoning as to the appropriate award for the applicant. ${ }^{53}$

It is common for the OHRT to justify a decision to not increase the general damages award by stating that it was precluded from doing so because the applicant failed to adduce medical evidence of any subjective consequences of the sexual harassment. This indicates the weight that is ascribed to medical evidence. In Payette $v$ Alarm Guard Security Service, ${ }^{54}$ the tribunal referenced the spectrum of damage awards from the jurisprudence, remarking that decisions on the higher end "involved circumstances in which touching occurred and/or medical issues resulted from the infringement," 55 neither of which were present in the case at bar. The tribunal noted that "although the applicant testified that she was emotionally upset, her testimony in this regard was for the most part general in nature," and "there was no evidence to support that the infringement in this matter caused her such upset that it resulted in a medical condition." $" 56$ The reasons here clearly indicate that medical evidence of an emotional or psychological impact would have elevated her damages award. The OHRT employed a similar justification in Iu $v$ Markham Marble. ${ }^{57}$ The tribunal found that the applicant made it clear that having to endure the harassment and discrimination during her employment with the respondent caused her immense distress, and therefore found "that she suffered injury to dignity, feelings and self-respect," entitling her to general damages. ${ }^{58}$ However, the fact that "the applicant offered no testimony with respect to any residual suffering after she ceased working with Mr. Fan" tempered its decision to award her higher compensation. "It does not appear," the OHRT reasoned, "that her

\footnotetext{
502014 HRTO 1652.

${ }^{51}$ Ibid at para 39.

52 Ibid at paras $41-42$.

${ }^{53}$ See e.g. Sanford v Koop, 2005 HRTO 53; SS, supra note 21; Newton, supra note 31; Hughes, supra note 29; SH, supra note 23 ; MK, supra note 31.

${ }^{54}$ Payette, supra note 49.

55 Ibid at para 54.

56 Ibid.

572012 HRTO 65.

${ }^{58}$ Ibid at para 35.
} 
distress with respect to the poisoned environment and Mr. Fan's behaviour was longterm." 59

In some decisions, such as in $G G \vee[\ldots]$ Ontario $L t d,{ }^{60}$ the tribunal actually decreased the award simply because no medical evidence was put forward. The OHRT explained their decision by stating that "the lack of medical evidence as to how the applicant has been affected and the fact that the applicant has not required medication or counseling lessens the weight I can give to her relatively brief evidence as to how the discrimination has affected her." 61 This result is particularly surprising given that the respondent in this case had already been convicted of sexual assault for his assault of the applicant. ${ }^{62}$

\section{No Medical Evidence, But the Applicant Still Resembled the "Ideal Victim"}

There have been some instances where the tribunal gave monetary compensation despite the applicant's failure to submit medical documentation into evidence. In these decisions, the tribunal was nevertheless willing to accept that the applicant had been detrimentally impacted by the respondent's conduct such that monetary compensation would be appropriate. It is clear that the tribunal was satisfied, either by observing the applicant on the stand or by witness corroboration, that the applicant had clearly been traumatized in some manner by the respondent. In Garofalo v Cavalier Hair Stylists Shop Inc, ${ }^{63}$ the OHRT stated:

I also accept the applicant's testimony, which was not shaken in crossexamination, that the individual respondent's comments to, and conduct towards, her had a significant impact on her, including instilling feelings of embarrassment and degradation, and damaging her self-confidence, self-esteem, and everything that made her feel good as a woman. ${ }^{64}$

Similarly, in Chard $v$ Newton, ${ }^{65}$ the tribunal found that the testimony of the applicant, Ms. Chard, "made it clear that this made her feel frightened and wary of men, and her testimony made clear the serious effects of having her bodily integrity violated" and that "[ $\mathrm{t}]$ he mental distress these events caused Ms. Chard was significant.",66

\footnotetext{
59 Ibid.

${ }^{60} G G$, supra note 22 .

${ }^{61}$ Ibid at para 26.

${ }^{62}$ Ibid at para 11.

${ }^{63}$ Garofalo, supra note 29.

${ }^{64}$ Ibid at para 290.

${ }^{65}$ Chard v Newton, 2007 HRTO 36.

${ }^{66}$ Ibid at paras 66, 69.
} 
Witness corroboration can also influence the OHRT's subjective impact analysis. In Smith $v$ The Rover's Rest ${ }^{67}$ the tribunal explained:

I also accept the applicant's testimony, which was not shaken in crossexamination and much of which was corroborated by her mother, that the individual respondent's comments and conduct had a significant impact on her, including depression, sleeping problems, lethargy, weight loss, damage to her relationship with her teenage daughter, and a fear of going outside alone, especially after dark. ${ }^{68}$

In these decisions, the emotional and/or psychological impact of sexual harassment was sufficiently evident to the OHRT that the lack of medical documentation was not determinative.

\section{Exceptional Cases}

In exceptional cases, the OHRT has declined to decrease awards despite the applicant not manifesting patent or medically substantiated signs of psychological or emotional injury. In the minority of cases, the absence of medical evidence or lack of the appearance of traumatization did not automatically give rise to a lesser damages award. In these decisions, the gravity of the facts seems to speak for itself in persuading the tribunal to presume that the conduct would have caused injury to "dignity, feelings and self-respect" and therefore that an appropriate award should be ordered. This was the case in Hill-LeClair v Booth, ${ }^{69}$ where the OHRT found that: "[t] he impact of sexual harassment by a landlord can be debilitating, and the effects can be long-term and profound." 70 Thus, "[d]espite the fact that the applicant did not adduce any medical evidence or expert testimony concerning the short and long term impact of the harassment on her health," the tribunal was satisfied "that the respondent's mistreatment had a negative psychological and emotional impact on the applicant." 71 Similarly in $C U$ $v$ Blencowe, ${ }^{72}$ the tribunal stated that it was "mindful that the applicant adduced very limited medical evidence, which did not disclose any diagnosis related to the harassment she experienced."73 Nevertheless, the OHRT concluded that it was reasonable that the respondent's actions resulted in a high level of anxiety and fear for

\footnotetext{
${ }^{67}$ Rover's Rest, supra note 31.

${ }^{68}$ Ibid at para 121.

${ }^{69}$ Hill-LeClair, supra note 36.

${ }^{70} \mathrm{Ibid}$ at para 46.

${ }^{71}$ Ibid.

${ }^{72}$ CU, supra note 29.

${ }^{73} \mathrm{Ibid}$, at para 35.
} 
the applicant. ${ }^{74}$ A third example of this exceptional approach is Panucci $v$ Seller's Choice Stockdale Realty $L t d,{ }^{75}$ where the tribunal was simply willing to accept that "[u]nwelcome comments about one's appearance or feeling that one has to submit to unwanted physical contact in the workplace are, by any objective standard, demoralizing in their impact and would leave most people feeling devalued and under stress,"76 thereby establishing grounds for general damages.

In these three cases, and in contrast to the decisions previously discussed, the OHRT did not require proof from the applicant that the experience of sexual harassment caused "injury to dignity, feelings and self-respect." Ironically, these three cases demonstrate that sometimes the objective part of the analysis is what affords the tribunal the flexibility to look at the big picture and avoid a formalistic approach when assessing a reasonable amount of damages.

However, these cases are the exception. Unfortunately, it is much more common for the OHRT to require some proof of subjective impact. Infrequently, the applicant's own testimony, if unshaken in cross-examination, is sufficient proof. In other circumstances, witness corroboration or medical documentation is necessary. Either way, the tribunal generally requires evidence of emotional or psychological distress. The more the applicant resembles the "ideal victim," appearing emotionally or psychologically traumatized, the better their chances of securing higher damages.

\section{PROBLEMS WITH THE OHRT'S APPLICATION OF SECTION 45.2}

Taken together, the thirty cases suggest an overarching pattern that the OHRT will expect an applicant to prove that he or she has suffered "injury to dignity, feelings and self-respect" even after the applicant has successfully proven sexual harassment on a balance of probabilities. The requirement that the applicant prove the emotional and psychological toll of the respondent's conduct is problematic for at least three reasons. First, for privacy reasons, applicants should not be compelled to surrender their medical records in order to secure better compensation. Second, claimants who already bear the burden of proving sexual harassment on a balance of probabilities should not bear an additional burden of proving with corroborative evidence the emotional or psychological injuries they have suffered. Third, the idea that individuals, particularly women, behave in some uniform traumatized manner once they have endured sexual assault or other forms of sexual harassment contradicts research ${ }^{77}$ and unjustly restricts

\footnotetext{
${ }^{74}$ Ibid.

752015 HRTO 1579 [Panucci].

76 Ibid at para 94.

${ }^{77}$ Karla Fischer, Louise F Fitzgerald \& Suzanne Swan, “Why Didn’t She Just Report Him? The Psychological and Legal Implications of Women's Responses to Sexual Harassment” (1995) 51:1 J Soc Issues 117, DOI: <10.1111/j.1540-4560.1995.tb01312.x>.
} 
the ability of claimants to secure higher compensation. The following section will elaborate on these three points.

\section{Applicants Should Not be Compelled to Surrender Medical Records}

It is hard to conceive of matters more private than a person's medical information. Medical records often contain both sensitive and compromising details about an individual's life, such as physical health, mental health, family history, social behaviours, personal relationships, and financial status. In Canada, we recognize that the confidentiality of such information is a right. For instance, public institutions are required by law to protect the confidentiality of such details and to obey strict rules when collecting and using personal information. ${ }^{78}$

In her thesis examining sexual assault and the criminal justice system in Canada, author Rose Mary Lynn Ubell asks: "What must a woman reveal about herself in order to access justice for a wrong committed against her, and how do these revelations subject her to further victimization?"79 Even in the criminal context, where the concern is balancing the plaintiff's privacy rights against the defendant's right to full answer and defence, there are restrictions on when an applicant can be compelled to produce personal medical records. ${ }^{80}$ The fact that, in this civil context, the OHRT has developed an expectation that applicants surrender confidential medical information is extreme. If an individual's right to privacy is safeguarded in the criminal sphere where competing fundamental interests are at stake, it should surely apply in the civil context. Applicants should not have to fear compromising their own right to privacy in order to secure proper compensation for injury done to them.

The requirement for medical proof is also unwarranted because it is a divergence from the stated requirements in the legislation and the initial case law interpreting section 45.2. There is no requirement for medical substantiation articulated in the language of section 45.2. ${ }^{81}$ Neither was any requirement for medical proof included in what was section 41(1) (the precursory provision to section 45.2), which was in effect until June 30, 2008. ${ }^{82}$ Some of the earliest case law interpreting the original damages provision explicitly states that medical evidence is not a requirement. In Ketola $v$ Value Propane Inc, ${ }^{83}$ a case interpreting the meaning of "mental anguish" under section 41(1),

\footnotetext{
${ }^{78}$ Freedom of Information and Protection of Privacy Act, RSO 1990, c F.31; Municipal Freedom of Information and Protection of Privacy Act, RSO 1990, c M.56; Personal Health Information Protection Act, 2004, SO 2004, c 3, Sched A.

${ }^{79}$ Rose ML Ubell, "Myths and Misogyny: The Legal Response to Sexual Assault" (2018) 4 Masters of Studies in Law Research Papers Repository 1 at 33, online (pdf): <ir.lib.uwo.ca/cgi/viewcontent.cgi ?article $=1005 \&$ context $=$ mslp $>$ [perma.cc/T654-S63Q].

${ }^{80}$ Criminal Code, RSC 1985, c C-46, s 278.5(2).

${ }^{81}$ Code, supra note $1, \mathrm{~s} 45.2$.

${ }^{82}$ Code, supra note 1, s 41(1) as it appeared on June 29, 2008.

83 (2002), 44 CHRR D/37 (Ont Bd Inquiry).
} 
the Board of Inquiry held that " $[\mathrm{t}]$ here is no requirement that medical evidence be given to substantiate the claim, although it may be useful to the Board." 84 In that case, the Board was satisfied that, despite a lack of medical expert evidence, "the actions of the Respondents exacerbated the stress and anxiety that [the applicant] experienced," entitling the applicant to general damages and mental anguish damages. ${ }^{85}$ Most importantly, in Janzen, the leading decision on section 45.2, there is no mention of an onus on the applicant to provide medical proof. ${ }^{86}$ In summary, the expectation today by the OHRT that applicants provide some sort of medical documentation in order to claim general damages under section 45.2 is a new threshold created by the tribunal that has no basis in the governing legislation or the leading case law. Nevertheless, this requirement has become increasingly pervasive and encumbers applicants' access to monetary compensation.

\section{Section 45.2 Creates an Additional Onus on the Applicant}

The tribunal's application of section 45.2 has had the effect of imposing an additional evidentiary burden on applicants. As the cases demonstrate, not only do applicants bear the onus of proving that sexual harassment took place, it is now effectively mandated that applicants also prove that they have suffered some visible emotional or psychological harm. Given that the evidentiary burden on the applicant is already high in sexual harassment and sexual assault cases, adding a new onus unjustifiably compounds the difficulties applicants face in an attempt to access justice.

When an applicant makes a claim of sexual harassment under the Code, they must prove on a balance of probabilities that the respondent committed sexual harassment. In other words, the applicant must prove that it is more likely than not that the harassment took place. In most cases of sexual harassment, the applicant is the sole witness for the claim, and the respondent denies the allegation. ${ }^{87}$ When there are no witnesses or tangible evidence to corroborate the applicant's claim, which is frequent in sexual harassment cases, proof of the events often boils down to the evidence of whichever party the tribunal finds more credible. ${ }^{88}$ However, the balance of probabilities test often requires clear and persuasive evidence, which can be an insurmountable burden to discharge when the incident occurs in a private setting. ${ }^{89}$

Offences of sexual violence, by their nature, place a great evidentiary burden on the applicant and increase the difficulty of making out their claim. Once the applicant

\footnotetext{
${ }^{84}$ Ibid at para 11.

${ }^{85}$ Ibid at para 7.

86 Janzen, supra note 4.

${ }^{87}$ Constance Backhouse, “Bell v The Flaming Steer Steak House Tavern: Canada’s First Sexual Harassment Decision" (1981) 19:1 UWOLR 141 at 145-46.

${ }^{88}$ See e.g. Faryna v Chorny, [1952] 2 DLR 354 (BCCA) cited in Panucci, supra note 75 at para 41.

${ }^{89} \mathrm{FH} v$ McDougall, 2008 SCC 53 at paras 46, 80.
} 
has discharged this burden, however, the OHRT should begin from the presumption that the applicant is entitled to a general damages award from the respondent for the breach of their rights under the Code. The tribunal should not impose an additional evidentiary burden on the applicant, further obstructing the difficult path applicants must take to obtain justice.

\section{Section 45.2 Perpetuates the Myth of the "Ideal Victim"}

The idea that individuals, particularly women, uniformly behave in a traumatized manner after enduring sexual assault is a common myth. Hasty assumptions such as "she is not injured," or "she is not upset," or "she didn't act like a victim," so "she must not have been sexually assaulted" feed into common rape myths that currently and historically have clouded the judgment of authorities in assessing whether an alleged sexual assault actually took place. ${ }^{90}$ For example, in a recent exposé on police investigations of sexual assault cases in Canada, the Globe and Mail reported that rape myths are one of the systemic issues prompting police to dismiss an unusually high rate of sexual assault allegations as "unfounded." 91

Behavioural science research on sexual harassment has likewise revealed that these common myths are inappropriate conceptual frameworks for sexual harassment cases. Indeed, scholarship investigating responses to sexual harassment highlights the fact that individuals do not always behave in the way society might expect. ${ }^{92}$ The impact of sexual harassment can be felt emotionally, psychologically, physically, socially, financially, professionally, and on many other levels. Individuals may not appear injured, upset, or victimized, and they may not express the experience as causing "injury to dignity, feelings and self-respect." For example, emotional distress may be displayed in unexpected ways, such as laughter. ${ }^{93}$ Some individuals behave enraged, having experienced a sudden, uncontrollable, and unpredictable threat to their safety. ${ }^{94}$ Other individuals, particularly women, who may be socialized to expect or tolerate certain levels of sexual violence, may appear unscathed after incidents of sexual harassment. ${ }^{95}$ An individual's response to sexual harassment is a complex process that

\footnotetext{
${ }^{90}$ See Jessica Shaw et al, "Beyond Surveys and Scales: How Rape Myths Manifest in Sexual Assault Police Records" (2017) 7:4 Psychol Violence 602, DOI: <10.1037/vio0000072〉.

${ }^{91}$ Robyn Doolittle, "Unfounded: Why Police Dismiss 1 in 5 Sexual Assault Claims as Baseless," The Globe and Mail (3 February 2017), online: <www.theglobeandmail.com/news/investigations/unfoundedsexual-assault-canada-main/article33891309> [perma.cc/3K4P-9K7L].

${ }^{92}$ Fischer, Fitzgerald \& Swan, supra note 77 at 130.

${ }^{93}$ Canadian Resource Centre for Victims of Crime, "The Impact of Victimization" (May 2011), online (pdf): Canadian Resource Centre for Victims of Crime <crcvc.ca/wp-content/uploads/2011/10/TheImpact-of-Victimization_may2011.pdf> [perma.cc/XK8B-T8TD].

${ }^{94}$ Ibid.

${ }^{95}$ Ibid.
} 
changes over time, depends on the individual's own characteristics, and fluctuates with changing environmental circumstances. ${ }^{96}$

The medical proof requirement also effectively forces applicants to seek-and potentially pay for-counselling or medical assistance. Logistically and economically, this is another burden on the applicant. One applicant should not be denied the same compensation as another who sought medical help simply because the former chose not, or did not have the means, to seek medical help. Because acts of sexual violence and coercion affect individuals differently, it is unwarranted to punish those who do not seek medical help for one reason or another. It is unreasonable to punish individuals for making personal choices that are their prerogative to make.

Sexual harassment affects everyone differently. The notion embedded in section 45.2 that applicants can be expected to manifest the injury they have suffered in some visible way, or that the worst forms of harassment are followed by medical attention, is a problematic approach to whether general damages should be warranted. This notion contradicts research on the non-uniformity of reactions to sexual harassment and it perpetuates the myth of the "ideal victim" that undermines the interests of applicants.

\section{ROOM FOR IMPROVEMENT}

Medical evidence can be relevant, and applicants should have the opportunity to enter medical documentation into evidence if they so wish. Medical disclosure, however, should only be voluntary, and applicants should not be expected or compelled to surrender personal medical details to the scrutiny of the OHRT and the respondent. Applicants certainly should not be penalized by the tribunal for choosing to keep their medical records confidential.

Applicants should also be permitted to have their reactions accepted by the tribunal and should not be penalized, in the form of lesser compensation, just because they may not appear to third parties as the "ideal victim." The idea that applicants must appear upset, injured, and victimized plays into myths surrounding sexual violence, and this conceptual framework is too narrow when assessing sexual harassment cases. There is sufficient social scientific research on this topic to disabuse the OHRT of the notion that the personal consequences of experiencing sexual harassment can be made visible to a panel of strangers. When ordering general damages, the OHRT should bear in mind the unpredictable ways in which an individual may respond to sexual harassment experiences. This would enable the tribunal to better serve the interests of applicants and human rights law in general.

\footnotetext{
${ }^{96}$ Fischer, Fitzgerald \& Swan, supra note 77.
} 
In addition, the OHRT may wish to reconsider its approach to the general damages remedy when handling sexual harassment cases. If so, scholars and experts on sexual harassment, as well as sexual violence awareness groups, would be useful resources.

\section{CONCLUSION}

There is no doubt that there were good intentions behind the subjective impact analysis. Clearly, the purpose is to gain a better understanding of the applicant's perspective on the offence committed and to factor into the award the often intangible and unquantifiable consequences that come with sexual harassment. The subjective impact analysis can provide applicants an opportunity to share their experience and receive compensation even if the facts do not appear severe at first instance.

However, when the recent cases are viewed together, there are significant flaws in the current approach. The overemphasis on medical proof of emotional suffering acts as a barrier to justice. It creates a new evidentiary burden for applicants and forces them to choose between preserving their privacy and seeking justice. More generally, the OHRT should recognize that applicants will not always express their emotions, or articulate the injuries they have suffered, in a manner comprehensible to the tribunal. Furthermore, since the additional evidentiary burden was neither legislated nor established in the leading case law, there is no persuasive reason to preserve it. Until the OHRT is willing to address these issues, its current application of section 45.2 will continue to silence the experiences of applicants who do not fit the "ideal victim" stereotype and deny those individuals their equal rights to be protected from sexual harassment. 


\section{APPENDIX A: LIST OF OHRT DECISIONS}

Arunachalam v Best Buy Canada Ltd, 2010 HRTO 1880 (CanLII)

Chard v Newton, 2007 HRTO 36 (CanLII)

Chuvalo v Toronto Police Services Board, 2010 HRTO 2037 (CanLII)

CK v HS, 2014 HRTO 1652 (CanLII)

CU v Blencowe, 2013 HRTO 1667 (CanLII)

Cugliari v Telefficiency Corporation, 2006 HRTO 7 (CanLII)

de los Santos Sands v Moneta Marketing Solutions Inc, 2016 HRTO 271 (CanLII)

Garofalo v Cavalier Hair Stylists Shop Inc, 2013 HRTO 170 (CanLII)

GGv [...] Ontario Limited, 2012 HRTO 1197 (CanLII)

Harriott v National Money Mart, 2010 HRTO 353 (CanLII)

Hill-LeClair v Booth, 2009 HRTO 1629 (CanLII)

Horner v Peelle Company Ltd, 2014 HRTO 1211 (CanLII)

Hughes $v 1308581$ Ontario, 2009 HRTO 341 (CanLII)

Iu v Markham Marble, 2012 HRTO 65 (CanLII)

$J D v$ The Ultimate Cut Unisex, 2014 HRTO 956 (CanLII)

Manu v Centum Fundamental Financial Inc, 2015 HRTO 725 (CanLII)

MK v [...] Ontario, 2011 HRTO 705 (CanLII)

Murchie v JB's Mongolian Grill, 2006 HRTO 33 (CanLII)

Newton $v$ Toronto (City), 2010 HRTO 1023 (CanLII)

OPT v Presteve Foods Ltd, 2015 HRTO 675 (CanLII)

Panucci v Seller's Choice Stockdale Realty Ltd, 2015 HRTO 1579 (CanLII)

Payette v Alarm Guard Security Service, 2011 HRTO 109 (CanLII)

Ratneiya v Daniel \& Krumeh, 2009 HRTO 1824 (CanLII)

Sanford v Koop, 2005 HRTO 53 (CanLII)

SH v M[...] Painting, 2009 HRTO 595 (CanLII)

Smith v Menzies Chrysler, 2009 HRTO 1936 (CanLII)

Smith $v$ The Rover's Rest, 2013 HRTO 700 (CanLII)

SS v Taylor, 2012 HRTO 1839 (CanLII)

Vipond v Ben Wicks Pub and Bistro, 2013 HRTO 695 (CanLII)

Wesley v 2252466 Ontario Inc, 2014 HRTO 1591 (CanLII) 